\title{
Comb and Propolis Waxes from Brazil (States of São Paulo and Paraná)
}

\author{
Giuseppina Negri $^{a}$, Maria Cristina Marcucci $^{a}$, Antonio Salatino ${ }^{b^{*}}$ and Maria Luiza F. Salatino \\ ${ }^{\mathrm{a}}$ Universidade Bandeirante de São Paulo, Rua Maria Cândida, 1813, 02071-013, São Paulo - SP, Brazil \\ bInstituto de Biociências, Universidade de São Paulo, CP 11461, 05422-970, São Paulo - SP, Brazil
}

\begin{abstract}
Amostras de ceras do ninho e da própolis de Apis mellifera foram analisadas. Observou-se a predominância de ésteres, seguidos de hidrocarbonetos. Os constituintes foram identificados por cromatografia a gás/espectrometria de massas. Amplas variações foram observadas nos padrões de hidrocarbonetos e dos ácidos e álcoois de ésteres. As cadeias carbônicas dos hidrocarbonetos abrangem a faixa $\mathrm{C}_{23}-\mathrm{C}_{35}$, com o predomínio de $\mathrm{C}_{27} \mathrm{e}_{31}$. O principal ácido carboxílico foi $\mathrm{C}_{16: 0}$, seguido de $\mathrm{C}_{18: 0}$ e $\mathrm{C}_{18: 1}$. Os principais álcoois constituintes de ésteres foram homólogos saturados normais, na faixa $\mathrm{C}_{24}-\mathrm{C}_{32}, \mathrm{C}_{30}$ sendo o mais abundante, seguido de $\mathrm{C}_{24}$. Não foram observadas diferenças que permitam distinção, o que sugere uma origem comum para ambas as fontes de cera.
\end{abstract}

Samples of propolis and comb waxes of Apis mellifera were analyzed. Monoesters predominated, followed by hydrocarbons. The constituents were identified by gas chromatography/mass spectrometry. Wide variations in the patterns of hydrocarbons, acids and alcohols of the esters were found. Hydrocarbon chains cover the range $\mathrm{C}_{23}-\mathrm{C}_{35}, \mathrm{C}_{27}$ and $\mathrm{C}_{31}$ alkanes predominating. The main carboxylic acid was $\mathrm{C}_{16: 0}$, followed by $\mathrm{C}_{18: 0}$ and $\mathrm{C}_{18: 1}$. The alcohols were predominantly saturated $n$-homologues, ranging from $\mathrm{C}_{24}$ to $\mathrm{C}_{32}, \mathrm{C}_{30}$ being the most abundant, followed by $\mathrm{C}_{24}$. No differences were found to allow a distinction, suggesting a common origin for both wax sources.

Keywords: propolis wax, beeswax, Apis mellifera

\section{Introduction}

Propolis is a complex mixture of waxes, resins and other organic and inorganic compounds used by bees as a general sealer, draught excluder and antibiotic ${ }^{1-3}$. Bees use propolis to prevent decomposition of creatures such as beetles and mice which they have killed after invasion of the hive ${ }^{4}$. Propolis derived products are widely used in folk medicine and reputedly have antibacterial, antimycotic, anti-inflammatory and other pharmacological properties ${ }^{1}$.

The term "waxes" is used to designate mixtures of longchain non-polar compounds commonly found mainly on the surfaces of plants and animals ${ }^{5}$. Commercially, beeswax is the most important natural wax. It is obtained chiefly from the domesticated European honey bee Apis mellifera, although other important taxa exist, such as the Asiatic A. dorsata, A. florea and A. indica and the African A. mellifera adansonii. Aliphatic saturated and monounsaturated compounds are major comb wax constituents ${ }^{6,7}$. The composition of comb wax is dependent on the genetics of the insects ${ }^{8}$. European and African bees produce waxes with different hydrocarbon patterns ${ }^{9,10}$ and the process of bee africanization may be detected by analysis of the hydrocarbons encountered in bee products $^{11}$. Recent analysis of comb wax using two-stage resolution of mixtures of heterogenous compounds by supercritical fluid chromatography ${ }^{12}$ revealed hydrocarbons, esters of higher alcohols and fatty acids and free higher fatty acids among the wax constituents.

Samples of propolis contain a whitish material which can be extracted by treatment with hot chloroform. This substance has a composition similar to comb wax ${ }^{13}$ and is apparently secreted by the bees. In comparison with comb wax, much less is known about the composition of propolis wax. Negri et al. ${ }^{13}$ observed that monoesters and hydrocarbons are the predominant constituents of propolis wax. Alkanes, alkenes, alkadienes, diesters, ketones and fatty acids, previously reported as propolis constituents ${ }^{14,15}$, are classes of compounds commonly found as natural wax substances.

In Brazil, there has been extensive hybridization between the European bees A. mellifera mellifera and A. mellifera ligustrica with the African bee A. mellifera adansonii (=A. m. scutellata) after the introduction of the latter in the 1950 's ${ }^{16}$. Contemporarily, all honey bees found in Brazil are said to be Africanized. The present work presents data of propolis wax from Brazilian localities not included in reference 13 . In addition, it includes information 
about comb wax, for the purpose of comparison between the composition of the waxes from both natural sources.

\section{Results and Discussion}

The contents of wax in the collected samples of comb and propolis are presented in Table 1. The values for the samples of propolis range from $4.8 \%$ to $19.3 \%$. Apparently, there is no correlation between the percentages and sites of collection. The yields are relatively small compared with those of Bonvehí et al. ${ }^{17}$, who found values close to $30 \%$ for samples from China. The contents of wax in samples of comb collected in two cities of the state of São Paulo are much lower $(1.5 \%$ and $3.0 \%)$ than the contents found in samples of propolis. Table 1 also presents the percentages of the constituent hydrocarbons and monoesters of the samples of comb and propolis waxes. In both sources, monoesters are clearly the predominant class of constituents, followed by hydrocarbons. Similar results were obtained by Negri et al. ${ }^{13}$ for samples of propolis waxes. There is no homogeneity in the results and no correlation with locality. The compositions of comb and propolis waxes are probably more dependent on the genetic characteristics of the bees than on the site of collection. In fact, different degrees of hybridization have been found to occur between European and African bees in Brazil ${ }^{16,18,19,20}$.

Table 2 shows the distribution of the hydrocarbon fraction of comb and propolis waxes. A wide variation in the hydrocarbon patterns among the samples is visible. Most samples of comb (1c, $2 c$ and $4 c$ ), as well as propolis ( $2 p, 5 p$, $6 \mathrm{p}, 7 \mathrm{p}, 8 \mathrm{p}$ and $9 \mathrm{p}$ ), presented heptacosane as the main component. This alkane has been referred to as the main hydrocarbon of both comb wax ${ }^{9}$ and propolis wax ${ }^{13}$. The comb wax sample $3 \mathrm{c}$ and that of propolis $1 \mathrm{p}$ presented the alkene $\mathrm{C}_{33}$ as the main hydrocarbon. Other authors $9,14,21$ have reported the predominance of alkenes in comb wax. The main hydrocarbon of propolis samples $3 \mathrm{p}, 4 \mathrm{p}$ and $10 \mathrm{p}$ was $\mathrm{C}_{31}$. Occasionally, branched alkanes (iso-alkanes) were found in low amounts and exclusively in propolis waxes (samples 1p, 6p and 7p, Table 2). No correlation is apparent between hydrocarbon patterns and localities, contrary to what is known about the composition of the constituents of propolis resin, which is dependent on the local flora ${ }^{1}$. A possible explanation for differences in hydrocarbon patterns between colonies may lie in genetic factors ${ }^{8,11}$, particularly in bee populations from Brazil, which are the result of different levels of hybridization (see Introduction). However, high levels of consistency within and among families of bees has been found by means of correlation analysis ${ }^{8}$, indicating structural constancy in comb wax. Analyses of surface hydrocarbons also indicated that a significant proportion of the variation among bees may be attributable to genetic factors ${ }^{22}$. Some insect surface compounds may also be important constituents of comb wax, as are the cases of the hydrocarbons $\mathrm{C}_{27}$ and $\mathrm{C}_{29}$ (but not $\mathrm{C}_{31}$ ) and the carboxylic acid $\mathrm{C}_{14}$. It is interesting to note that the latter acid has been found neither in samples of wax of Brazilian propolis analyzed by Negri et al. ${ }^{13}$ nor in the samples of the present work.

The need to hydrolyze the esters for identification of the constituent acid and alcohol residues is a shortcoming in the analysis of natural waxes, because the outcome is only a partial analysis of the product. Under suitable conditions it is possible to analyze intact high molecular weight esters $9,23,24,25$. Novel techniques involving high temperature gas chromatography have enabled the direct analyses of seed triglycerides ${ }^{26}$ and propolis extracts 27,28 without derivatization. In the present work the analysis of the ester fraction followed the conventional procedure of hydrolysis and derivatization prior to GC/MS analysis.

Table 1. Sites of collection of comb (c) and propolis (p) and respective contents (w/w) of wax, hydrocarbons and monoesters. No example of comb and propolis from the same hive is presented.

\begin{tabular}{lccc}
\hline Sample and site of collection & $\begin{array}{c}\text { Wax } \\
(\%)\end{array}$ & $\begin{array}{c}\text { Hydrocarbons } \\
(\%)\end{array}$ & $\begin{array}{c}\text { Monoesters } \\
(\%)\end{array}$ \\
\hline 1c. Atibaia, state of São Paulo & 1.5 & 23.5 & 71.8 \\
2c. Jundiaí, state of São Paulo & 3.0 & 25.2 & 67.4 \\
3c. Jundiaí, state of São Paulo & 3.0 & 15.1 & 75.8 \\
4c. Jundiaí, state of São Paulo & 3.0 & 16.4 & 69.4 \\
1p. Atibaia, state of São Paulo & 18.0 & 28.0 & 67.2 \\
2p. Bragança Paulista, state of São Paulo & 14.8 & 32.5 & 59.8 \\
3p. Bragança Paulista, state of São Paulo & 9.0 & 15.9 & 74.3 \\
4p. Bragança Paulista, state of São Paulo & 6.6 & 6.4 & 73.6 \\
5p. Bragança Paulista, state of São Paulo & 11.8 & 13.8 & 68.3 \\
6p. Jundiá́, state of São Paulo & 4.8 & 24.9 & 72.1 \\
7p. Jundiaí, state of São Paulo & 14.9 & 13.3 & 77.1 \\
8p. Ribeirão Preto, state of São Paulo & 19.3 & 33.3 & 49.2 \\
9p. Ribeirão Preto, state of São Paulo & 17.4 & 20.7 & 59.5 \\
10p. Ponta Grossa, state of Paraná & 14.5 & 2.0 & 73.1 \\
\hline
\end{tabular}


The distribution of the alcohols of monoesters covered the range $\mathrm{C}_{24}-\mathrm{C}_{32}$ in both sources of waxes (Table 3). Neither branched nor unsaturated homologues were detected. Similar results have been reported for propolis waxes ${ }^{13}$. In general the most abundant homologue in both wax types was $\mathrm{C}_{30}$, but some samples ( $3 \mathrm{c}, 4 \mathrm{c}, 7 \mathrm{p}-9 \mathrm{p}$, Table
3) presented $\mathrm{C}_{24}$ as the main compound. For some samples (1c, 2c, 1p and 6p, Table 3) $\mathrm{C}_{32}$ was an important component. In most samples, however, it was a minor constituent of the ester fraction and, in some samples (2p, $7 \mathrm{p}$ and $10 \mathrm{p}), \mathrm{C}_{32}$ was not detected.

Palmitic acid $\left(\mathrm{C}_{16}\right)$ was the dominant homologue of

Table 2. Percentual distribution of homologues in the hydrocarbon fraction of samples of propolis (p) and comb (c). Unless stated, numbers of carbon atoms correspond to normal chains; iso $=2$-methyl isomers; colon followed by digit 1 indicates one unsaturation. Digits in sample column correspond to samples listed in Table 1.

\begin{tabular}{|c|c|c|c|c|c|c|c|c|c|c|c|c|c|c|c|c|c|}
\hline Sample & $\mathrm{C}_{21}$ & $\mathrm{C}_{22}$ & $\mathrm{C}_{23}$ & $\mathrm{C}_{24}$ & $\mathrm{C}_{25}$ & $\mathrm{C}_{26}$ & $\mathrm{C}_{27}$ & $\mathrm{C}_{28}$ & $\mathrm{C}_{29}$ & $\begin{array}{l}\text { iso } \\
\mathrm{C}_{29}\end{array}$ & $\mathrm{C}_{30}$ & $\mathrm{C}_{31}$ & $\mathrm{C}_{31: 1}$ & $\begin{array}{l}\text { iso } \\
\mathrm{C}_{31}\end{array}$ & $\mathrm{C}_{33}$ & $\mathrm{C}_{33: 1}$ & $\mathrm{C}_{35: 1}$ \\
\hline $1 \mathrm{c}$ & 1 & & 3 & 2 & 9 & 3 & 24 & 3 & 16 & & & 19 & 2 & & & 15 & 2 \\
\hline $2 \mathrm{c}$ & 1 & 1 & 2 & 1 & 13 & 1 & 30 & 1 & 16 & & 1 & 17 & 2 & & 3 & 3 & 2 \\
\hline $3 c$ & & & & & 3 & & 12 & & 1 & & & & & & & 80 & 4 \\
\hline $4 c$ & & & 1 & & 7 & 2 & 30 & 3 & 16 & & 2 & 19 & & & 5 & 9 & 4 \\
\hline $1 p$ & & & 2 & & 7 & & 20 & & 12 & 2 & & 22 & 3 & 2 & & 25 & 3 \\
\hline $2 p$ & & & & & 19 & & 45 & & 14 & & 2 & 12 & & & 1 & 3 & 4 \\
\hline $3 p$ & & & & & 4 & & 32 & & 18 & & & 40 & & & 3 & & \\
\hline $4 p$ & & & & & 4 & & 33 & & 20 & & & 40 & & & 3 & & \\
\hline $5 p$ & & & & & 8 & & 36 & & 21 & & & 28 & & & 3 & 4 & \\
\hline $6 p$ & & & 2 & 1 & 6 & 1 & 28 & 1 & 17 & 4 & 1 & 21 & 1 & 2 & 3 & 9 & 2 \\
\hline $7 p$ & & & & & 8 & & 30 & & 13 & & & 24 & & 2 & 2 & 19 & 2 \\
\hline $8 p$ & & & 7 & & 17 & & 30 & & 7 & & & 6 & & & 5 & 28 & 4 \\
\hline $9 p$ & & & 8 & & 18 & & 28 & & 8 & & & 6 & 5 & & & 23 & 3 \\
\hline $10 p$ & & & & & & & 20 & & 22 & & & 53 & & & 5 & & \\
\hline
\end{tabular}

Table 3. Percentual distribution of $n$-primary alcohols and $n$-carboxylic acids of monoesters from samples of propolis (p) and comb (c) waxes. Colon followed by digit 1 indicates one unsaturation. Digits in sample column correspond to samples listed in Table 1.

\begin{tabular}{|c|c|c|c|c|c|c|c|c|c|c|}
\hline Sample/ Fraction & $\mathrm{C}_{16}$ & $\mathrm{C}_{18}$ & $\mathrm{C}_{18: 1}$ & $\mathrm{C}_{20}$ & $\mathrm{C}_{22}$ & $\mathrm{C}_{24}$ & $\mathrm{C}_{26}$ & $\mathrm{C}_{28}$ & $\mathrm{C}_{30}$ & $\mathrm{C}_{32}$ \\
\hline \multicolumn{11}{|l|}{ Alcohols } \\
\hline $1 \mathrm{c}$ & & & & & & 15 & 13 & 18 & 40 & 14 \\
\hline $2 \mathrm{c}$ & & & & & & 20 & 17 & 18 & 29 & 16 \\
\hline $3 c$ & & & & & & 60 & 14 & 12 & 12 & 2 \\
\hline $4 c$ & & & & & & 43 & 12 & 10 & 29 & 6 \\
\hline $1 \mathrm{p}$ & & & & & & 6 & 9 & 17 & 42 & 26 \\
\hline $2 \mathrm{p}$ & & & & & & 28 & 20 & 21 & 31 & \\
\hline $3 p$ & & & & & & 32 & 18 & 11 & 37 & 2 \\
\hline $4 p$ & & & & & & 6 & 6 & 10 & 73 & 5 \\
\hline $5 \mathrm{p}$ & & & & & & 25 & 7 & 12 & 54 & 2 \\
\hline $6 \mathrm{p}$ & & & & & 1 & 12 & 13 & 22 & 41 & 11 \\
\hline $7 p$ & & & & & & 40 & 28 & 14 & 18 & \\
\hline $8 \mathrm{p}$ & & & & & & 30 & 21 & 19 & 22 & 8 \\
\hline $9 \mathrm{p}$ & & & & & & 39 & 20 & 17 & 21 & 3 \\
\hline $10 \mathrm{p}$ & & & & & & 8 & 3 & 17 & 72 & \\
\hline \multicolumn{11}{|l|}{ Acids } \\
\hline $1 \mathrm{c}$ & 100 & & & & & & & & & \\
\hline $2 \mathrm{c}$ & 56 & 33 & 11 & & & & & & & \\
\hline $3 c$ & 100 & & & & & & & & & \\
\hline $4 c$ & 55 & 14 & 4 & 1 & 2 & 16 & 4 & 3 & & \\
\hline $1 \mathrm{p}$ & 80 & & 5 & & & 15 & & & & \\
\hline $2 p$ & 76 & 4 & 12 & & & & & & & \\
\hline $3 p$ & 100 & & & & & & & & & \\
\hline $4 p$ & 69 & 17 & 8 & 1 & 2 & 3 & & & & \\
\hline $5 p$ & 100 & & & & & & & & & \\
\hline $6 p$ & 58 & 32 & 9 & 1 & & & & & & \\
\hline $7 p$ & 29 & 11 & 27 & 2 & 5 & 17 & 4 & 3 & & \\
\hline $8 p$ & 74 & 4 & 18 & & & & & & & \\
\hline $9 \mathrm{p}$ & 72 & 5 & 18 & & & & & & & \\
\hline $10 \mathrm{p}$ & 100 & & & & & & & & & \\
\hline
\end{tabular}


the acyl portion of esters in all samples examined (Table 3 ), in agreement with previous findings about propolis wax ${ }^{13}$. Although no data were raised about chain lengths of intact esters in the present investigation, the fact that the main alcohol is in general $\mathrm{C}_{30}$ and the main acid is $\mathrm{C}_{16}$ suggests that triacontil palmitate $\left(\mathrm{C}_{46}\right)$ predominates among the esters of the samples of propolis and comb wax investigated. Esters ranging from $\mathrm{C}_{40}$ to $\mathrm{C}_{50}$ were found to occur in comb waxes of $A$. mellifera mellifera and $A$. mellifera adansonii, the most abundant being $\mathrm{C}_{46}{ }^{9}$. As in the cases of hydrocarbons and alcohols commented above, a wide variation of patterns of the acid portion of esters is observed in Table 3. For example, samples 1c, 3c, 3p, 5p and $10 \mathrm{p}$ presented exclusively palmitic acid. On the other hand, samples $4 \mathrm{c}$ and $7 \mathrm{p}$ yielded a long series of homologues ranging from $\mathrm{C}_{16}$ to $\mathrm{C}_{28}$; oleic acid is an important constituent in some samples ( 2 c, 2 p, $7 \mathrm{p}-9 \mathrm{p})$, but a minor or undetected component in other samples.

In spite of the wide variation observed in the distribution of the constituents of all fractions analyzed, there is a remarkable similarity between the composition of propolis wax and comb wax. The resin and the volatile fractions of propolis are presumably largely derived from plant secretions collected by bees ${ }^{1}$. Since plants produce waxes that coat all aerial cutinized parts 29,30 , the hypothesis could be raised that propolis wax might also be derived from plant secretions. But several differences can be pointed out between the composition of beeswax (as here reported) and plant waxes. For example, the latter rarely present alkenes and oleic acid as important hydrocarbon constituents ${ }^{29}, 30$, and esters may predominate in plant waxes, but not always. In contrast, monoesters always appeared consistently as the predominant class of propolis wax (Table 1).

\section{Experimental}

\section{Material}

Samples of propolis and comb waxes were collected from hives growing in the states of São Paulo and Paraná (Southeast and Southern Brazil, respectively) (Table 1).

\section{Extraction of the waxes}

Samples of propolis were extracted with chloroform in a Soxhlet extractor ${ }^{13}$. Amounts of comb ranging from 1.0 to $3.0 \mathrm{~g}$ were treated with boiling chloroform and filtered while still hot. The chloroform extracts were evaporated to dryness under reduced pressure and dried in a dessicator to constant weight (Table 1).
Separation and identification of constituent fractions

The fractions of constituents of propolis and comb waxes were separated by $\mathrm{CC}$, using silicagel and a mixture of solvents of increasing polarity ${ }^{13}$, and TLC, using silicagel impregnated with sodium fluoresceine and developing with a mixture of hexane: chloroform $(73: 27)^{13}$. Functional characterization of the constituent classes was achieved by IR spectroscopy with a Perkin Elmer model FTIR spectrophotometer. The esters were hydrolyzed with methanolic $\mathrm{KOH}$ and the resultant acid and alcohol fractions separated by means of extraction with chloroform after neutralization with $10 \% \mathrm{HCl}^{13}$. The acids were identified as the corresponding methyl esters and alcohols as the corresponding acetyl esters by GC/ electron impact mass spectrometry on an HP model 5890 series II GC interfaced with an HP 5989B ChemStation mass spectrometer using conditions identical to those cited in reference 13 .

\section{Acknowledgements}

The authors acknowledge financial support provided by FAPESP (Fundação de Amparo à Pesquisa do Estado de São Paulo) and CNPq (Conselho Nacional do Desenvolvimento Científico e Tecnológico).

\section{References}

1. Marcucci, M. C. Apidologie 1995, 26, 83.

2. Marcucci, M. C. Quim. Nova 1996, 19, 529.

3. Greenaway, W.; May, J.; Scaysbrook, T.; Whatley, F. R. Z. Naturforsch. C: J. Biosci. 1991, 46, 111.

4. Brumfitt, W.; Hamilton-Miller, J. M. T.; Franklin, I. Microbios 1990, 62, 19.

5. Hamilton, R. J. In Waxes: Chemistry, Molecular Biology and Functions; Hamilton, J. R., Ed.; The Oily Press; Dundee, 1995, p 257.

6. Kolattukudy, P. E. Chemistry and Biochemistry of Natural Waxes; Elsevier; Amsterdam, 1976.

7. Brossard, S.; Lafosse, M.; Dreux, M.; Becart, J.; Tranchant, J. F. Parf. Cosmét. Arômes 1994, 117, 48.

8. Breed, M. D.; Page, R. E.; Hibbard, B. E.; Bjostad, L. B. J. Chem. Ecol. 1995, 21, 1329.

9. Tulloch, A. P. Bee World 1980, 61, 47.

10. Hepburn, H. R. Honey Bees and Wax; Springer-Verlag; Berlin, 1986.

11. Carlson, D. A. In Africanized Honey Bees and Bee Mites; Needham, G. R.; Page, R. E.; Delfinado-Baker, M.; Bowman, C. E., Eds; Ellis Horwood Ltd.; Chichester, 1988, p 264. 
12. Takeuchi, M.; Saito, T. J. Chromatogr. 1996, 722,317

13. Negri, G.; Marcucci, M. C.; Salatino, A.; Salatino, M. L. F. Apidologie 1998, 29, 305.

14. Seifert, M.; Haslinger, E. Liebigs Ann. Chem. 1989, 1123.

15. Bankova, V.; Christov, R.; Stoev, G.; Popov, S. J. Chromatogr. 1992, 607, 150.

16. Lobo, J. A.; Del Lama, M. A.; Mestriner, M. A. Evolution 1989, 43, 794.

17. Bonvehí, J. S.; Coll, F. V. V.; Jordá, R. E. J. Am. Oil Chem. Soc. 1994, 71, 529.

18. Lobo, J. A.; Krieger, H. Heredity 1992, 68, 441.

19. Diniz-Filho, J. A. F.; Malaspina, O. Evolution 1995, 49, 1172.

20. Diniz-Filho, J. A. F. J. Apic. Res. 1996, 35, 104.

21. Seifert, M.; Haslinger, E. Liebigs Ann. Chem. 1991, 93.

22. Page, R. E.; Metcalf, R. A.; Metcalf, R. L.; Erickson, E. H.; Lampman, R. L. J. Chem. Ecol. 1991, 17,745 .
23. Gülz, P. G.; Müller, E. Z. Naturforsch. 1992, 47, 800.

24. Summchen, P.; Markstadter, C.; Wienhaus, O. Phytochemistry 1995, 40, 599.

25. Shepherd, T.; Robertson, G. W.; Griffiths, D. W.; Birch, A. N. E. Phytochemistry 1997, 46, 83.

26. Reiter, B.; Lechner, M.; Lorbeer, E.; Aichholz, R. J. High Resolut. Chromatogr. 1999, 22, 514.

27. Pereira, A. S.; Pinto, A. C.; Cardoso, J. N.; Aquino Neto, F. R. ; Ramos, M. F. S.; Dellamora-Ortiz, G. M.; Santos, E. P. J. High Resolut. Chromatogr. 1998, 21, 396.

28. Pereira, A. S.; Ramos, M. F. S.; Poças, E. S. C.; Dias, P. C. M.; Santos, E. P.; Silva, J. F.; Cardoso, J. M.; Aquino Neto, F. R. Z. Naturforsch. 1999, 54, 395.

29. Baker, E. A. In The Plant Cuticle; Cutler, D. F.; Alvin, K. L.; Price, C. E., Eds; Academic Press; New York, 1982, p 139.

30. Bianchi, G. In Waxes: Chemistry, Molecular Biology andFunctions; Hamilton, R. J., Ed.; The Oily Press; Dundee, 1995, p 175.

Received: April 08, 1999

Published on the web: August 31, 2000

FAPESP helped in meeting the publication costs of this article. 